\title{
Personality and Attitude towards Teaching Profession: Mediating Role of Self Efficacy
}

\author{
Mehmet Üstüner \\ Correspondence: Mehmet Üstüner, Faculty of Education, İnönü University, Malatya, Turkey. \\ Received: July 13, 2017 \\ doi:10.11114/jets.v5i9.2536 \\ Online Published: August 7, 2017 \\ Accepted: August 1, 2017 \\ URL: https://doi.org/10.11114/jets.v5i9.2536
}

\begin{abstract}
The objective of the present study is to examine the correlation between the five factor personality traits of pre-service teachers and their attitudes towards the teaching profession and to test the mediating role of the pre-service teachers' self-efficacy beliefs. The study population included pre-service teachers that attended the "pedagogical formation course" instructed / applied in İnönü University, Faculty of Education, Department of Educational Sciences in 2015-2016 academic year. The survey sample included 382 pre-service teachers who voluntarily responded to the measurement instruments utilized in the study. The study data were collected with the "five factor personality scale", "attitudes towards the teaching profession scale" and "teacher self-efficacy scale". The obtained data were analyzed with path analysis of structural equation modeling. In conclusion, it was observed that there was a significant positive correlation between the five factor personality traits of extraversion, conscientiousness, openness and agreeableness and teacher self-efficacy belief, and there was a significant negative correlation between neuroticism personality trait and teacher self-efficacy belief. It was observed that the self-efficacy beliefs of pre-service teachers played a full mediating role between their neuroticism, openness and extraversion personality traits, and the same played a partial mediating role in the correlation between conscientiousness and agreeableness personality traits and the attitude towards the teaching profession. The implementation of a curriculum in pre-service teacher training that would increase the self-efficacy beliefs on teaching would also improve their attitudes towards the profession positively.
\end{abstract}

Keywords: five factor personality traits, pre-service teachers, teaching profession, self-efficacy

\section{Introduction}

Teacher training, which is considered as the most important and critical element in the formal education system, is one of the primary problem areas in several educational systems. This problem has been one of the significant problem areas in the Turkish education system. Since the inauguration of the first teachers' training school in 1846 in the Turkish education system, different teacher training practices have been conducted parallel to the demographic, political, economic, cultural developments. Today, the pedagogical formation courses, which are one of the teacher training applications, are organized to certify teachers which is necessary to become a teacher that several students trained in different faculties that do not aim to train teachers desire to find jobs. The majority of students who enroll in these courses attend or have attended higher education programs that these students applied after secondary education are not directly teacher training programs. For example, students who prefer departments in the Faculty of Theology, Faculty of Engineering, Faculty of Economics and Administrative Sciences, School of Nursing, Science and Literature, etc., primarily desire to be employed in professions related to their field, but since it is a problem to find a job in their fields, they are finally forced to become teachers. The preference to become a teacher is not the primary career choice for these students. Thus, determining the correlation between the personality traits of students participating in pedagogical formation courses as pre-service teachers and their attitudes towards the profession, and the extent to which their perception of teacher self-efficacy mediates this correlation are significant issues.

Individuals make career choices mostly during high school years (14-18 years of age). Individuals that select faculties and faculty programs after high school do so based on their personal traits (personality, interests, values, expectations, etc.). Personality is one of the important factors that affect individual's career choices. In addition to having a high level of occupational satisfaction and motivation (Crant, 2006), it is stated that those who work at a job that is suitable to personal traits achieve significant opportunities to satisfy their psychological needs. Individuals' adequate career choices is considered significant in protecting their psychological health (Brown, 2003). 
Personality is defined as intellectual, affective, and behavioral differences that distinguish individuals from others (Hockenbury \& Hockenbury, 2010). Personality can also be defined as distinctive and characteristic patterns of thoughts, emotions, and behavior that define the way an individual interacts with the physical and social environment (Atkinson et al., 1999). Personality traits that are defined as consistent behavioral patterns and self-processes originating from the individual (Burger, 2006) are often described as a tendency of an individuals to demonstrate a certain behavior under changing situations. It is expected that an individual with certain personality traits would behave in a particular way in different situations, and personality traits could be defined as permanent qualities that enable individuals to exhibit consistent behavior under different conditions (Shaw, 1981; Gerrig \& Zimbardo, 2014). Personality is effective in determining how an individual would behave in different situations. There were several theories such as psychoanalytic, behavioral, characteristic properties, biological, humanistic and cognitive theories (Burger, 2006) that aimed to describe and define personality throughout history. The five-factor personality model, which is within the realm of the characteristic properties theory, was regarded as a generally accepted approach even though there are disagreements about the fact that it was structured within the framework of certain properties (Goldberg, 1990; Atkinson, Smith, Bem \& Hoeksema, 1999). One of the benefits of tackling personality with a characteristic feature approach is that it makes it easier to compare individuals (Burger, 2006).

In the five-factor personality model, adjectives used in daily language about personality traits are used (Goldberg, 1981; Salgado, Viswesvaran \& Önes, 2001). One of the most important reasons for the use of the five-person trait model commonly among many personality traits models is the consistency of this model in defining the personality (Bacanli, Ilhan \& Aslan, 2009). The five factor model organizes personality traits using five categories and defines the differences in personality. These five factors include the dimensions of openness, conscientiousness, extraversion, agreeableness and neuroticism (Costa \& McCrae, 1995; Burger, 2006; Cicarelli \& White, 2016).

Openness: Individuals with the openness personality trait are individuals who are willing to try new things, open to different experiences, versatile, creative, susceptible to changes in the environment, imaginative and risk-taking individuals, and individuals with low openness personality traits are more conventional and individuals who prefer to practice the known instead of trying the new.

Conscientiousness: It was stated that individuals with high conscientiousness personality traits are characterized by attentive behavior, high self-discipline and consistent in displaying similar behavior and individuals with high conscientiousness personality traits are characterized by inattentive, unorganized, indecisive and unreliable behavior.

Extraversion: It was stated that the individuals with high extraversion personality traits are social, energetic, optimistic, warm-blooded, amiable and sociable individuals and those with low extraversion personality traits are lonely, independent individuals who act / demonstrate slow behavior.

Agreeableness: It was emphasized that individuals with high agreeableness personality traits are easygoing, friendly, charitable, compassionate, gentle, cooperative and trustworthy, and individuals with low agreeableness personality traits exhibit skeptic, quarrelsome, contemptuous and competitive behavior.

Neuroticism: Individuals with high neuroticism personality traits are extremely scrupulous and anxious, pessimistic and experience negative emotions such as sadness, anger and guilt more intensely, and individuals with low neurotic personality traits are those who are calm, agreeable individuals who are not prone to excessive and disagreeable reactions (Costa \& McCrae, 1995; Burger, 2006; Ciccarelli \& White, 2016).

Hartman and Betz (2007) stated that there was a significant correlation between personality traits of the individuals and career development / career behavior. It was emphasized that "conscientiousness" and "extraversion" were the most reliable indicators of career-based self-efficacy, while it was supported that "neuroticism" is a continuous indicator of unproductivity when career behavior is analyzed based on personality traits. While "openness" had a more discontinuous but often positive correlation with career productivity, "agreeableness" had demonstrated almost no correlation with career productivity. It was reported that there was a significant correlation between "extraversion", "agreeableness" and "conscientiousness" and teachers' job satisfaction, while there was a negative correlation between "neuroticism" and teachers' job satisfaction (Pandey \& Kavitha, 2015).

In a study conducted on the correlation between personality traits of pre-service teachers and teaching performances, personality and teacher self-efficacy beliefs after completing teacher training (Jamil, Downer \& Pianta, 2012), it was determined that pre-service teachers with "extraversion" personality traits had higher teacher self-efficacy beliefs. Furthermore, it was observed that pre-service teachers with a "neuroticism" personality traits were less confident about their future achievements. It was found that both personality traits and self-efficacy of teachers were strongly associated with their teaching performance. However, it was found that teachers' self-efficacy beliefs predicted teaching efficiency more than the personality traits (Klassen \& Tze, 2014). It was indicated that "conscientiousness" and "openness" were the most important predictors of teacher self-efficacy (Djigic, Stojiljkovic \& Doskovic, 2013). Of the five major 
personality traits, "extraversion" and "agreeableness" were found to be related to the motivation to choose a teaching career among pre-service. Pre-service teachers with high extraversion, agreeableness, and conscientiousness were observed to have more intrinsic motivation towards teaching (Jogovic, Marusic, Ivanec \& Vidovic, 2012).

In a study on the correlation between organizational commitment and five major personality traits (Erdheim, Wang \& Zickar, 2006), it was found that extraversion was significantly associated with affective commitment, continuance commitment and normative commitment. Furthermore, a significant correlation between neuroticism, conscientiousness, openness, and continuance commitment, and a significant correlation between agreeableness and normative commitment were found. It was also reported that increasing positive affections of employees played a positive mediating role between extroversion and agreeableness personality traits and affective, continuance, and normative commitments, while increased negative affections played a positive mediating role between agreeableness personality trait and affective commitment (Panaccio \& Vandenberghe, 2012). It was observed that the individuals' self-efficacy beliefs were a significant mediating variable between the perceived stress levels and the five factor personality traits (Ebstrup, Eplov, Pisinger \& Jorgensen, 2011). It was observed that conscientiousness and agreeableness traits were more associated with organizational citizenship (Berry, Li \& Gardner, 2011). It was reported that individuals with extroversion and agreeableness personality traits among the five factor personality traits preferred / used the "confrontation" conflict resolution approach more (Basım, Çetin \& Tabak, 2009).

The concept of self-efficacy is based on Bandura's Social Learning Theory $(1986,1989)$. Self-efficacy is defined as the self-perception, belief, and judgment of the individual about coping with different situations, organizing activities necessary to demonstrate a certain performance, and succeeding in that performance. Individuals' self-efficacy beliefs might be high or low depending on past experiences in similar situations (success or failure), the views of other individuals on their qualifications, and their assessments about their own skills (Ciccarelli \& White, 2016). According to Bandura's self-efficacy theory, our motivation to succeed and perform well in a variety of tasks and situations depends largely on how much we believe in our own skills. While some individuals could have high self-efficacy belief that applies to several situations (sports, social interaction, academic achievement, etc.), some other could only have a self-efficacy belief on specific cases (computer use, playing a musical instrument, role playing, etc.) (Plotnik, 2009). Thus, teacher self-efficacy beliefs also reflect the individual's self-efficacy beliefs for a specific situation (learning-teaching).

According to Tschannen-Moran and Woolfolk Hoy (2001), teacher self-efficacy is "the judgment of a teacher on whether she or he could produce the desired results such as commitment and learning in a student with the skills the teacher has". The teacher self-efficacy is the answer given by the teacher to the question "Am I able to plan and implement the ideas and actions needed to perform my tasks?" (Goddard, Hoy \& Woolfolk-Hoy, 2004). In studies conducted to determine self-efficacy beliefs of pre-service teachers in Turkey (Özdemir, 2008; Azar, 2010; Demirtaş, Cömert \& Özer, 2011; Kutlucan \& Ekici, 2010; Saracaloglu \& Yenice, 2009; Kahyaoglu \& Yangin, 2007; Tarkin \& Uzuntiryaki, 2007), it was observed that pre-service teachers' self-efficacy beliefs were high. Furthermore, it was reported that female pre-service teachers had higher self-efficacy beliefs when compared to male pre-service teachers, and those who preferred the profession primarily were more likely to have higher self-efficacy beliefs (Özdemir, 2008). It was reported that teachers with high self-efficacy beliefs were less likely to quit the profession (Jamil, Downer \& Pianta, 2012). There were significant differences between teachers' self-efficacies based on their branches and satisfaction with the work environment (Saracaloglu \& Yenice, 2009). The level of self-efficacy beliefs of pre-service teacher differed significantly based academic achievement levels and their fields (Azar, 2010).

There were intermediate positive correlations between pre-service teachers' attitudes towards computer-aided education and self-efficacy beliefs (Kutluca \& Ekici, 2010), problem solving skills and self-efficacy beliefs (Yenice, 2012) and attitudes towards the teaching profession and self-efficacy beliefs (Demirtas \& Özer, 2011; Tarkın \& Uzuntiryaki).

One of the significant areas of research in every social science (e.g., economics, psychology, sociology, law, etc.) that focuses on understanding and explaining human behavior in a specific field is attitudes of the individuals. Attitude is defined as "a structure that prioritizes behavior, guides choices and decisions about the action, although it is not directly observable" (Hogg \& Vaughan, 2007). Attitude is a tendency that is attributed to an individual and regularly constructs ideas, emotions and behavior about a psychological object (Kağıtçıbaş1, 2010). Attitudes are expressions of positive or negative assessments about objects, individuals or events. Attitudes reflect the feelings of an individual about something (Robbins \& Judge, 2012).

Knowing the attitude of an individual towards an object or a stimulus would make it possible to predict the behavior of the same individual towards the related stimulus. When teacher behavior is analyzed in a classroom environment, it could be observed that one of the main factors determining teacher behavior was the quality of the attitude of the individual towards the profession. In this context, several studies were conducted in Turkey to determine the levels of positive or negative attitudes of pre-service teachers towards the teaching profession. (e.g., Pehlivan, 2010; Kad1, 
Beytekin \& Arslan, 2015; Kutlu, Gökdere \& Çakır, 2015; Ekici, Çıbık \& Fettahlıoğlu, 2014; Demirtaş \& Aksoy, 2015; Oguz \& Kalkan, 2011).

It was determined that pre-service teachers using a differentiating and internalizing learning style had a more positive attitude towards the teaching profession (Pehlivan, 2010). It was stated that motivation levels of pre-service teachers were a significant predictor of their attitudes towards the teaching profession (Ömür \& Nartgün, 2013). Attitudes of pre-service teachers towards the teaching profession differ based on their fields. There was a negative significant relationship between the burnout level of pre-service teachers (Kad1, Beytekin \& Arslan, 2015), procrastination behavior (Gökdere \& Çakır, 2015) and their anxiety levels towards the profession and positive attitudes towards the teaching profession. It was determined that there was a negative correlation between pupil control ideologues of pre-service teachers and their attitudes towards the teaching profession, and the attitude towards the teaching profession was a significant predictor of pupil control ideology (Oguz \& Kalkan, 2011). It was emphasized that there was a significant correlation between teaching motivations of pre-service teachers and their attitudes towards the profession and positive attitudes towards the profession was a significant predictor of internal and external motivations of pre-service teachers (Ayık \& Ataş, 2014). It was determined that there was a significant correlation between pre-service teachers' self-efficacy beliefs and their attitudes towards the teaching profession (Ekici, Çıbık \& Fettahlığlu, 2014; Demirtaş, Cömert \& Özer, 2011). Based on the results of certain studies (Fadlelmula, 2013; Terzi \& Tezci, 2007), it was determined that female pre-service teachers had more positive attitudes towards the teaching profession when compared to male pre-service teachers, in certain others (Demirtaş \& Aksoy, 2015; Demirtas, Cömert \& Özer, 2011), it was found that there was no significant difference between female and male teachers' attitudes towards the profession. It was observed that there was a significant difference between the attitudes of pre-service teachers who choose the teaching profession for internal reasons and the attitudes of pre-service teachers who choose the teaching profession for external reasons in a study conducted by Üstüner, Demirtaş \& Cömert (2009).

Findings of the abovementioned studies demonstrated that in studies conducted on the personality traits, self-efficacy beliefs and attitudes towards the teaching profession of pre-service teachers, these topics were investigated separately bases on certain individual / demographic variables, however in certain others, paired comparative studies such as personality traits - self-efficacy beliefs, self-efficacy beliefs - attitudes toward the teaching profession, personality traits - attitudes towards the profession, etc. The main hypotheses of the present study that aimed to test the correlation between the five factor personality traits of pre-service teachers and their attitudes towards the teaching profession and the mediating role of teacher self-efficacy beliefs on this correlation are presented below.

H1: "Extroversion" personality trait of pre-service teachers has a positive significant effect on teacher self-efficacy beliefs.

H2: "Conscientiousness" personality trait of pre-service teachers has a positive significant effect on teacher self-efficacy beliefs.

H3: "Openness" personality trait of pre-service teachers has a positive significant effect on teacher self-efficacy beliefs.

H4: "Agreeableness" personality trait of pre-service teachers has a positive significant effect on teacher self-efficacy beliefs.

H5: "Neuroticism" personality trait of pre-service teachers has a negative significant effect on teacher self-efficacy beliefs.

H6: "Extroversion" personality trait of pre-service teachers has a positive significant effect on their attitudes towards teaching profession.

H7: "Conscientiousness" personality trait of pre-service teachers has a positive significant effect on their attitudes towards teaching profession.

H8: "Openness" personality trait of pre-service teachers has a positive significant effect on their attitudes towards teaching profession.

H9: "Agreeableness" personality trait of pre-service teachers has a positive significant effect on their attitudes towards teaching profession.

H10: "Neuroticism" personality trait of pre-service teachers has a negative significant effect on their attitudes towards teaching profession.

H11: "Teacher self-efficacy beliefs" of pre-service teachers has a positive significant effect on their attitudes towards teaching profession.

H12: Teacher self-efficacy beliefs has a mediating role in the correlation between five factor personality traits of pre-service teachers and their attitudes towards the teaching profession. 


\section{Method}

Relational survey methodology is a research model that aims to determine the presence and / or the degree of correlations between two or more variables (Cohen, Manion \& Morrison, 2007; Fraenkel \& Wallen, 2003). In the study, a model that predicts that the five factor personality traits of pre-service teachers both directly and indirectly affect their attitudes towards the teaching profession through their self-efficacy beliefs was proposed. To test the model, a path analysis was conducted using the variables observed within the structural equation modeling. The proposed model is presented in Figure 1.

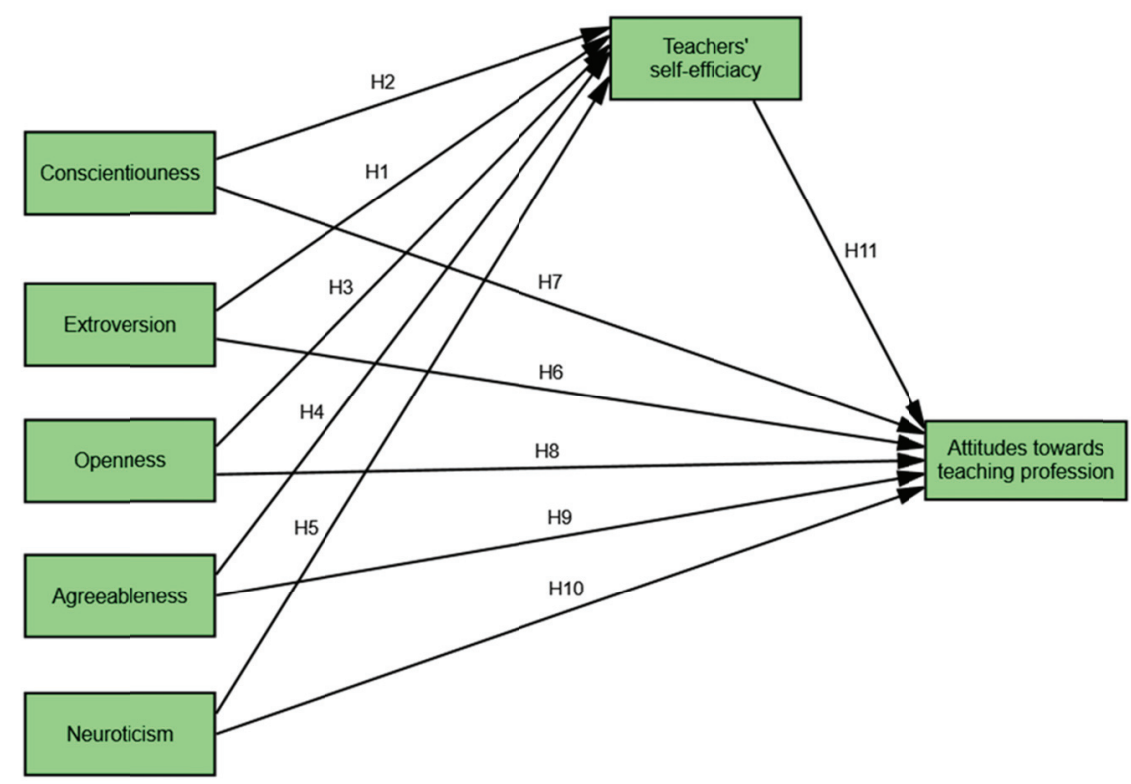

Figure 1. The proposed model on the correlation between five factor personality traits, attitude towards the teaching profession and self-efficacy beliefs

Pre-service teachers' self-efficacy beliefs were considered as both dependent and independent variables with the anticipation that they might have direct or indirect impact on attitudes towards the teaching profession. In other words, the self-efficacy beliefs of pre-service teachers was considered as the dependent variable with the anticipation that it would be affected by five-factor personality traits and was considered as independent variable with the anticipation that it would affect the attitude towards the teaching profession. In this constructed conceptual model, each path depicted by arrows revealed the cause-and-effect relationship between the variables.

\subsection{Population and Sample}

The population of the study included the pre-service teachers participating in the "pedagogical formation course" instructed in Inönü University, Faculty of Education, Department of Educational Sciences in 2015-2016 academic year. Students who attend different departments (Science, Literature, Theology, Fine Arts, Engineering, Economic Administrative Sciences, Health Sciences) and desire to work as teachers could register in this course based on their academic achievement scores and the quotas allocated to the faculty departments. The data collection instrument was distributed to 800 students attending in the pedagogical formation course in the said academic year and the study sample constituted the 382 pre-service teachers who voluntarily responded to the measurement instruments. $63.1 \%(\mathrm{n}=241)$ of the participants were female and $36.9 \%(n=141)$ were male pre-service teachers. Participants' average age was 22 .

\subsection{Data Collection Instruments}

The data required to test the hypotheses of the study were collected by "five factor personality traits scale", "teacher self-efficacy beliefs scale", and "attitudes towards teaching profession scale". These three scales, combined with a questionnaire that collected the demographic / personal information about pre-service teachers were given to pre-service teachers. It took approximately 30 minutes to fill out the combined instrument.

\subsubsection{Five Factor Personality Traits Scale (FFPTS)}

The FFPTS was developed by John, Donahue and Kentle (1991) in order to obtain a five-person personality scale that was easy to implement, short and suitable for inter-lingual and intercultural use. The adaptation of the scale to Turkish language was conducted by Sumer and Sumer within the context of an international project (Schmitt, Allik, McCrae \& Benet-Martinez, 2007). 
The measurement model was tested to satisfy an important assumption in the path analysis that was conducted in the study. For this purpose, confirmatory factor analysis (CFA) was conducted to test the validity of the scale. The goodness of fit indices $(\chi 2 / \mathrm{df}=1236.95 / 726=1.70 ; \mathrm{GFI}=.85 ; \mathrm{CFI}=.92 ; \mathrm{RMSEA}=.043 ; \mathrm{TLI}=.92)$ obtained from the CFA analysis demonstrated that the scale was fit for model measurement. Based on the data obtained with the conducted CFA analysis, Item 2 (looking for errors of others), Item 12 (constantly bickering with others), and Item 27 (could be cold and distant) in the "agreeableness" dimension of the scale and Item 35 (prefers routine tasks) in the "openness" dimension were excluded from the model since they did not demonstrate a significant correlation with the latent variable they intended to measure. Within the scope of the present study, Cronbach alpha internal consistency coefficient for the "openness" dimension subscale in the five factor personality scale was .90 , Cronbach alpha internal consistency coefficient for the "extraversion" subscale was .87, Cronbach alpha internal consistency coefficient for the "conscientiousness" subscale was .89, Cronbach alpha internal consistency coefficient for "agreeableness" subscale was .82, Cronbach alpha internal consistency coefficient for "neuroticism" subscale was .86.

\subsubsection{Teacher Self-efficacy Scale}

The original form of the "teacher self-efficacy beliefs scale" was developed by Tschannen-Moran \& Hoy (2001) and Turkish adaptation was conducted by Çapa, Çakıroğlu \& Sarıkaya (2005). Çapa, Çakıroğlu \& Sarıkaya (2005), who conducted the Turkish adaptation study, stated that the scale had model goodness of fit. In the adaptation study, the internal consistency coefficients calculated for each dimension were .82 for the "achieving student participation" dimension, .84 for the "classroom management" dimension and .86 for the "instructional strategies" dimension. The results of confirmatory factor analysis (CFA) conducted in this study were as follows: $(\chi 2 / \mathrm{df}=431.12 / 246=2.24$; $\mathrm{GFI}=.92 ; \mathrm{CFI}=.96 ; \mathrm{RMSEA}=.044 ; \mathrm{TLI}=.99)$ and demonstrated the model had goodness of fit. Based on the study data, Cronbach alpha internal consistency coefficient for the teacher self-efficacy scale "achieving student participation" dimension was .85 , Cronbach alpha internal consistency coefficient for the "instructional strategies" subscale was .87 , and Cronbach alpha internal consistency coefficient for the "classroom management" dimension was . 88 .

\subsubsection{Attitude towards Teaching Profession Scale}

The "attitude towards teaching profession scale" developed by Üstüner (2006) was used to determine the attitudes of pre-service teachers towards the teaching profession in the present study. A high score on the scale means that the attitudes toward the teaching profession were positive and a low means the attitudes were negative. It was stated that the criterion validity of the scale was ".89", reliability coefficient for score stability was ".72" and internal consistency coefficient was ".93" (Üstüner, 2006). Goodness of fit indices obtained as a result of the confirmatory factor analysis (CFA) conducted on the attitudes towards teaching profession scale in the present study $(\chi 2 / \mathrm{df}=1090.48 / 488=2.24$; $\mathrm{GFI}=.84 ; \mathrm{CFI}=.94 ; \mathrm{RMSEA}=.057 ; \mathrm{TLI}=.93)$ demonstrated that the scale had model goodness of fit. The Cronbach Alpha internal consistency coefficient for the scale was found as .97 as a result of the analyzes conducted in this study. During the analysis of the Item 32 (I do not like to talk about education, learning, instruction, teaching) on the scale, it was found that the item factor load was below .30, and the item was excluded from the analysis.

\subsection{Data Analysis}

Descriptive analyzes were conducted and missing data were checked, Mahanalobis distance was calculated to determine outliers, single and multivariate normality (Kurtosis and Skewness, Kolmogrov-Smirnov and Shapiro-Wilk, PP plot graphs, Mardia's multivariate normality coefficient and critical rate (cr) value), linearity (scatter matrix diagram), and multi-correlativity (correlation and VIF and tolerance values) were tested. As a result of the analyses, it was determined that the standalone study variables distributed normally, but they did not exhibit normal distribution as a whole in the study. Confirmatory factor analysis was conducted with the computer-assisted statistical software to test the fitness of the study instrument (scale) with the study data, and the Cronbach alpha internal consistency coefficients were calculated for the scales. The measurement model was included in the model using the verified scales, and since the assumption of multivariate normality was not met, a sample size of 1000 at the $95 \%$ confidence level was adapted for an error-free sample and corrected bootstrap analysis (non-parametric) was conducted. Thus, direct and indirect effects are calculated with the above mentioned method.

\section{Results}

In the first step of the analysis, the mean scores, standard deviations, and correlations between these scores were examined for the scores that pre-service teachers received in the five factor personality traits, the teacher self-efficacy, and the attitudes towards teaching profession scales. In the second step, mediation effect was investigated by hierarchical regression analysis. Then, a path analysis was conducted based on the model established by the structural equation model. The means, standard deviations and correlation values obtained as a result of the analyses are presented in Table 1. 
Table 1. Descriptive statistics and correlations among variables

\begin{tabular}{|c|c|c|c|c|c|c|c|c|c|}
\hline Variables & $x$ & $\mathrm{Sd}$ & 1 & 2 & 3 & 4 & 5 & 6 & 7 \\
\hline 1.Extraversion & 3.48 & .77 & 1 & & & & & & \\
\hline 2.Conscientiousness & 3.95 & .60 & $.26^{* *}$ & 1 & & & & & \\
\hline 3.Openness & 3.59 & .71 & $.39^{* *}$ & $.39^{* *}$ & 1 & & & & \\
\hline 4.Neuroticism & 2.27 & .62 & $-.29^{* *}$ & $-.33^{* *}$ & $-.30^{* *}$ & 1 & & & \\
\hline 5.Agreeableness & 3.87 & .60 & $.17^{* *}$ & $.39^{* *}$ & $.31^{* *}$ & $-.31^{* *}$ & 1 & & \\
\hline 6.Teaching Attitude & 4.18 & .65 & $.23^{* *}$ & $.37^{* *}$ & $.33^{* *}$ & $-.32^{* *}$ & $.32^{* *}$ & 1 & \\
\hline 7.Teacher Self-Efficacy & 3.99 & .46 & $.39^{* *}$ & $.48^{* *}$ & $.46^{* *}$ & $-.39^{* *}$ & $.37^{* *}$ & $.51^{* *}$ & 1 \\
\hline
\end{tabular}

$* * \mathrm{p}<0.01$

As seen in Table 1, it could be observed that there were significant positive correlations between all variables in the study model except "neuroticism" $(\mathrm{p}<0.01)$. Of the five factor personality traits, it was observed that there were positive moderate correlations between "extroversion" and teacher self-efficacy $(r=0.39 ; \mathrm{p}<0.01)$, between "conscientiousness" and teacher self-efficacy $(\mathrm{r}=0.48 ; \mathrm{p}<0.01)$, between "openness" and teacher self-efficacy $(\mathrm{r}=0.46, \mathrm{p}<0.01)$, and between "agreeableness" and teacher self-efficacy $(\mathrm{r}=0.37 ; \mathrm{P}<0.01)$, whereas there was a negative significant relationship between five factor personality trait of "neuroticism" and teacher self-efficacy $(r=-0.39 ; p<0.01)$. Of the five factor personality traits, it was observed that there were positive moderate correlations between "extroversion" and attitude towards teaching profession $(\mathrm{r}=0.23 ; \mathrm{p}<0.01)$, between "conscientiousness" and attitude towards teaching profession $(\mathrm{r}=0.37 ; \mathrm{p}<0.01)$, between "openness" and attitude towards teaching profession $(\mathrm{r}=0.33 ; \mathrm{p}<0.01)$, and between "agreeableness" and attitude towards teaching profession $(\mathrm{r}=0.32 ; \mathrm{p}<0.01)$, whereas there was a negative moderate correlation between five factor personality trait of "neuroticism" and attitude towards teaching profession ( $\mathrm{r}=$ $-0.32 ; \mathrm{p}<0.01)$. It was further observed that there was a positive and moderate significant correlation between pre-service teachers' self-efficacy beliefs and their attitudes towards teaching profession.

The path diagram and standardized predicted values obtained as a result of the analysis conducted in the research model are presented in Figure 2.

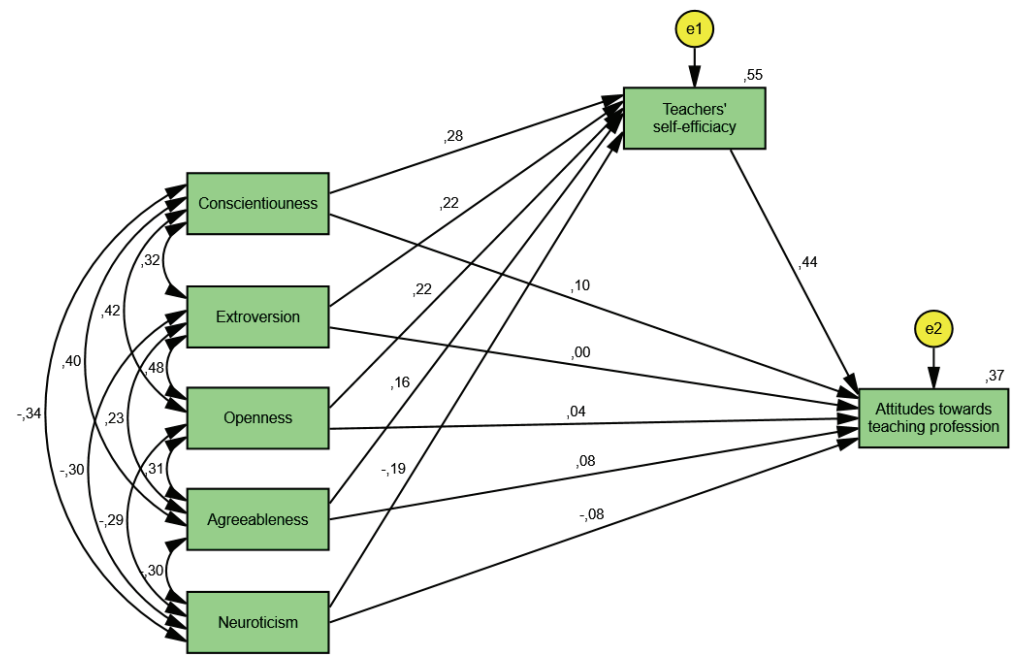

Figure 2. The path diagram and standardized predicted values obtained from the analysis conducted in the research model 
The predicted values for the model with the path diagram displayed in Figure 2 are presented in Table 2.

Table 2. Analysis results of the predicted values for the model

\begin{tabular}{lclccccc}
\hline \multicolumn{2}{l}{ Paths Between the Variables } & B & $\boldsymbol{\beta}$ & S.E. & C.R.(t) & P \\
\hline Self-Efficacy & $<---$ & Conscientiousness & .238 & .275 & .035 & 6.72 & $* * *$ \\
Self-Efficacy & $<---$ & Agreeableness & .115 & .157 & .028 & 4.04 & $* * *$ \\
Self-Efficacy & $<---$ & Neuroticism & -.121 & -.191 & .024 & -4.99 & $* * *$ \\
Self-Efficacy & $<---$ & Openness & .123 & .221 & .023 & 5.27 & $* * *$ \\
Self-Efficacy & $<---$ & Extroversion & .097 & .222 & .017 & 5.52 & $* * *$ \\
Attit. Teaching & $<---$ & Agreeableness & .115 & .083 & .064 & 1.79 & .073 \\
Attit. Teaching & $<---$ & Conscientiousness & .171 & .104 & .083 & 2.05 & .040 \\
Attit. Teaching & $<---$ & Openness & .043 & .041 & .054 & .79 & .425 \\
Attit. Teaching & $<---$ & Neuroticism & -.093 & -.078 & .055 & -1.67 & .094 \\
Attit. Teaching & $<---$ & Extroversion & -.003 & -.004 & .040 & -.07 & .941 \\
& & & .829 & .439 & .114 & 7.29 & $* * *$ \\
Attit. Teaching & $<---$ & Self-Efficacy & .074 & & & & \\
\hline
\end{tabular}

$\mathrm{p}<.05$

In Table 2, it is observed that certain paths between the variables in the research model were significant $(p<.05)$ while others were insignificant ( $p>.05$ ). After the model was re-analyzed by deleting the insignificant paths one by one, the resulting model where all paths are significant is presented in Figure 3.

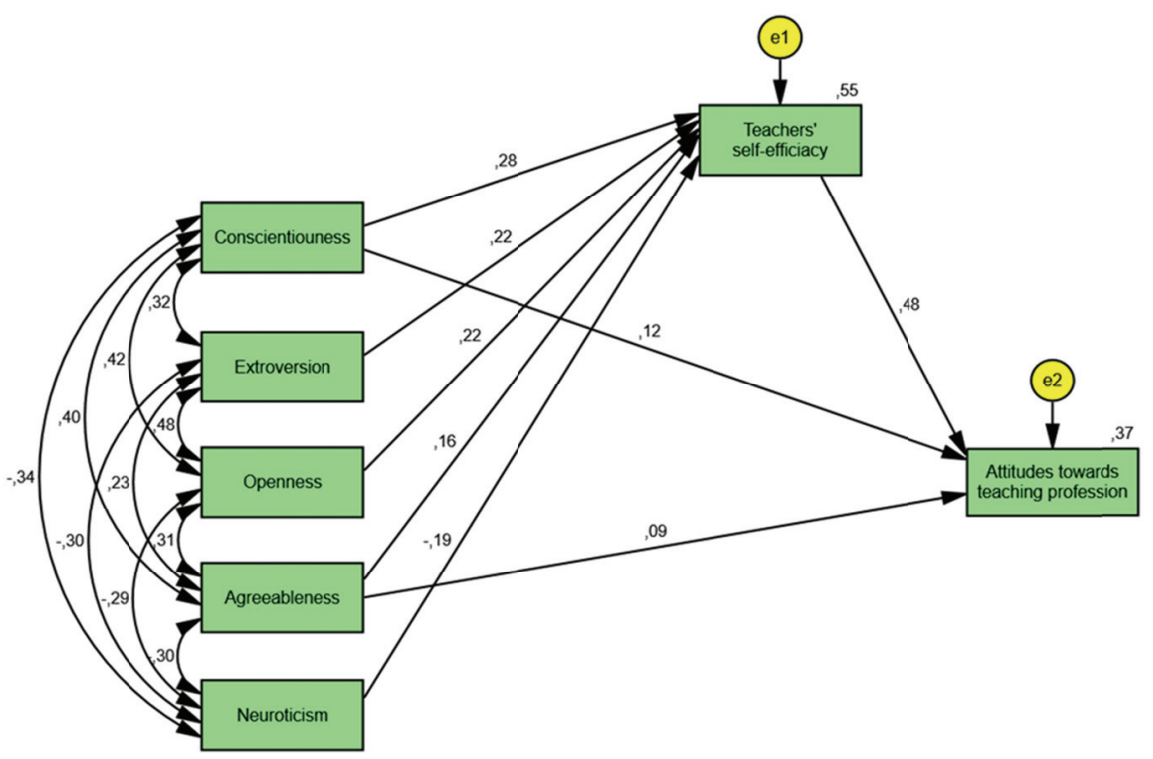

Figure 3. Final path analysis of the model

Fitness values in the final model that are presented in Figure 3 demonstrate that the fitness values are at an excellent level $(2 / \mathrm{sd}=3.539 / 3=1.18$; GFI=.997; CFI=.999; TLI (NNFI)=.995; RMSEA=.022). Estimates for the final model are presented in Table 3.

Table 3. Analysis results of final path analysis model

\begin{tabular}{lclccccc}
\hline \multicolumn{1}{l}{ Paths Between the Variables } & & B & $\boldsymbol{\beta}$ & S.E. & C.R.(t) & p \\
\hline Self-Efficacy & $<---$ & Conscientiousness & .238 & .275 & .035 & 6.72 & $* * *$ \\
Self-Efficacy & $<---$ & Agreeableness & .115 & .157 & .028 & 4.04 & $* * *$ \\
Self-Efficacy & $<---$ & Neuroticism & -.121 & -.191 & .024 & -4.99 & $* * *$ \\
Self-Efficacy & $<---$ & Openness & .123 & .221 & .023 & 5.27 & $* * *$ \\
Self-Efficacy & $<---$ & Extroversion & .097 & .222 & .017 & 5.52 & $* * *$ \\
Attit. Teaching & $<---$ & Agreeableness & .130 & .094 & .064 & 2.02 & .043 \\
Attit. Teaching & $<---$ & Conscientiousness & .191 & .117 & .082 & 2.31 & .020 \\
Attit. Teaching & $<---$ & Self-Efficacy & .913 & .483 & .097 & 9.38 & $* * *$ \\
\hline
\end{tabular}

$\mathrm{p}<.05$ 
According to Table 3, all paths in the final model were significant $(\mathrm{p}<.05)$. In this context, it was found that pre-service teachers conscientiousness $(\beta=.275 ; p<.05)$, agreeability $(\beta=.157 ; p<.05)$, openness $(\beta=.221 ; p<.05)$ and extroversion $(\beta=; \mathrm{P}<.05)$ personality traits had a direct positive effect on teacher self-efficacy beliefs, while neuroticism $(\beta=-.191$; $\mathrm{p}<.05)$ personality trait had a direct negative effect on teacher self-efficacy beliefs. Furthermore, it was observed that pre-service teachers' agreeableness $(\beta=.094 ; \mathrm{p}<.05)$ and conscientiousness $(\beta=.117 ; \mathrm{p}<.05)$ personality traits and teacher self-efficacy beliefs $(\beta=.483 ; p<.05)$ had a direct positive and significant effect on their attitudes towards teaching profession. Based on Figure 3, pre-service teachers' conscientiousness, agreeableness, extroversion and neuroticism personality traits explained $55 \%$ of the variance in teacher self-efficacy beliefs, while conscientiousness and agreeableness personality traits and teacher self-efficacy beliefs explained $37 \%$ of the variance in attitude towards teaching profession. Based on these findings, it could be stated that H1, H2, H3, H4, H5, H7, H9 and H11 hypotheses were accepted, while H6, H8 and H10 hypotheses were rejected.

Another hypotheses tested in the study was whether teacher self-efficacy beliefs play a mediating role between the five factor personality traits of pre-service teachers and their attitudes towards the teaching profession. Shrout and Bolger (2002) proposed the bootstrap method, which is an empirical method for determining the parameter estimates of the distribution in testing the significance level of indirect (mediating) effects. Thus, the bootstrap method was used to test the significance of indirect or mediation effect in the current study. In this context, the sample count of 382 was recreated as 1000 using debugged and corrected bootstrap method within $95 \%$ confidence interval and analyzed with AMOS software. The results of the analysis are presented in Table 4.

Table 4. Total, direct and indirect effects of pre-service teachers' five factor personality traits on the attitude towards teaching profession

\begin{tabular}{llllllll}
\hline & & & & & & \multicolumn{2}{c}{$\begin{array}{l}\text { Bootstrapping } \\
\text { \% 95 Confidence Interval }\end{array}$} \\
\cline { 3 - 8 } Effects & Total & Direct & Indirect & SH & p & \multicolumn{2}{c}{ Low Level High Level } \\
\hline Neuroticism & -.092 & .000 & -.092 & .021 & .002 & -.137 & -.053 \\
Openness & .107 & .000 & .107 & .023 & .002 & .062 & .156 \\
Extroversion & .107 & .000 & .107 & .022 & .002 & .064 & .152 \\
Conscientiousness & .250 & .117 & .133 & .024 & .002 & .088 & .185 \\
Agreeableness & .170 & .094 & .076 & .020 & .002 & .040 & .116
\end{tabular}

According to Table 4 , pre-service teachers' openness $(\beta=.107 ; \mathrm{p}<.05)$, extroversion $(\beta=.107 ; \mathrm{p}<.05)$, conscientiousness $(\beta=0.133 ; p<.05)$ and agreeableness $(B=-.092 ; p<.05)$ personality traits indirectly and positively affected the attitude towards the teaching profession through teacher self-efficacy beliefs, while neuroticism $(\beta=-.092 ; \mathrm{p}<.05)$ personality trait indirectly and negatively affected the attitude towards the teaching profession via teacher self-efficacy beliefs. The total, direct and indirect effects presented in Table 4 showed that teacher self-efficacy belief played a full mediating role in the correlation between the pre-service teachers' neuroticism, openness and extroversion personality traits and attitudes towards the teaching profession, while teacher self-efficacy beliefs played a partial mediating role in the relationship between conscientiousness and agreeableness personality traits and attitudes towards the teaching profession. Based on these findings, it could be concluded that the research hypothesis H12 was accepted.

\section{Discussion}

Some of the results obtained in the present study, in which the correlation between the five factor personality traits of pre-service teachers and their attitudes towards the teaching profession, and the mediating effect of teacher self-efficacy beliefs on this correlation were investigated, were consistent with the findings of previous studies. It was determined in the present study that pre-service teachers' conscientiousness $(\beta=.275 ; \mathrm{p}<.05)$, agreeableness $(\beta=.157 ; \mathrm{p}<.05)$, openness $(\beta=.221 ; \mathrm{p}<.05)$ and extroversion $(\beta=.222 ; \mathrm{p}<.05)$ personality traits had a direct positive effect on teacher self-efficacy beliefs. This finding was consistent with the findings by Jamil, Downer \& Pianta (2012) and Djigic, Stojiljkovic \& Doskovic (2013). This result demonstrated that the research hypotheses H1, H2, H3 and H4 were accepted. It was found that neuroticism $(\beta=-191 ; \mathrm{p}<.05)$ personality trait had a direct negative and significant effect on teacher self-efficacy beliefs. It was reported that individuals with neurotic personality are extremely scrupulous and anxious, experience more negative emotions such as sadness, anger and guilt. Such a personality trait is expected to have negative effects on pre-service teachers' self-efficacy beliefs and the findings were consistent with previous studies (Klassen \& Tze, 2014). This finding demonstrated that the hypothesis H5 was accepted.

It was found that pre-service teachers' agreeableness $(\beta=.094 ; \mathrm{p}<.05)$ and conscientiousness $(\beta=.117 ; \mathrm{p}<.05)$ personality traits and teacher self-efficacy beliefs $(\beta=.483 ; \mathrm{p}<.05)$ had positive, direct and significant effect on their attitudes towards the teaching profession. This finding was consistent the findings of a study conducted by Jogovic, Marusic, Ivanec \& Vidovic (2012), who found that pre-service teachers with high extroversion, agreeableness, and 
conscientiousness personality traits had higher internal motivation toward teaching. It was reported that there was a positive significant correlation between positive attitudes towards the teaching profession and internal motivation towards teaching (Ayık \& Ataş, 2014). This result suggested that the study hypotheses H7 and H9 could be accepted. The finding of the present study that pre-service teachers' teacher self-efficacy beliefs had a positive effect on their attitudes towards the teaching profession was consistent with the studies by Ekici, Çıbık \& Fettahlığlu (2014) and Demirtaş, Cömert \& Özer (2011). This result demonstrated that the research hypothesis H11 could be accepted. Since teacher self-efficacy belief is the perspective and assessment of the pre-service teacher towards their knowledge, skills and abilities on the teaching profession, the positive correlation between high teacher self-efficacy belief and the positive attitudes towards the profession is an expected result.

There was no significant correlation between extroversion, openness and neuroticism five factor personality traits of pre-service teachers and their attitudes towards teaching profession. In other words, the extroversion, openness and neuroticism personality traits do not affect pre-service teachers' attitudes toward the profession. This finding suggested that hypotheses H6, H8 and H10 in the study were not accepted. It was reported that individuals with the openness personality trait are willing to try new things, open to different experiences, inquisitive, versatile thinking, creative, environmentally sensitive, imaginative, and risk-taking individuals, individuals with high extroversion personality trait are social, energetic, optimistic, warm-blooded, amiable and sociable, and those with high neuroticism personality trait tend to be more extremely scrupulous, anxious and pessimistic, and experience emotions such as sadness, anger and guilt more than others. It was observed that these traits were not directly related to the attitudes of pre-service teachers towards the profession.

The 12th research hypothesis was whether the correlation between the five factor personality traits of pre-service teachers and their attitudes towards the teaching profession was mediated by teacher self-efficacy beliefs. The analysis conducted to test this hypothesis showed that pre-service teachers' openness $(\beta=.107 ; \mathrm{p}<.05)$, extroversion $(\beta=.107$; $\mathrm{p}<.05)$, conscientiousness $(\beta=0.133 ; \mathrm{p}<.05)$ and agreeableness $(\beta=-.076 ; \mathrm{p}<.05)$ personality traits indirectly and positively affected attitudes toward teaching profession via teaching self-efficacy beliefs, while neuroticism $(\beta=-.092$; $\mathrm{p}<.05)$ personality trait indirectly and negatively affected attitudes toward teaching profession via teaching self-efficacy beliefs. Teacher self-efficacy belief played a full mediating role in the correlation between the neuroticism, openness and extroversion personality traits and attitudes towards teaching profession of pre-service teachers, while teacher self-efficacy belief played a partial mediating role in the correlation between conscientiousness personality trait and attitudes towards teaching profession. Based on these findings, it could be argued that the research hypothesis H12 was accepted.

Self-efficacy belief is in a way the answer given to the question "can I do this task?" The positive response of pre-service teachers to such a question that they ask covertly to themselves would mean that their attitude towards the teaching profession is also positive. Self-efficacy beliefs play a full mediating role in the correlation between the personality traits of neuroticism, openness and extroversion and attitudes towards the profession, while self-efficacy belief plays a partial mediating role in the correlation between conscientiousness personality trait and attitudes towards the profession. The implementation of a curriculum that aims to increase the self-efficacy beliefs of pre-service teachers in teacher training would also mean that this would in turn contribute to their positive attitudes towards the profession.

\section{References}

Atkinson, R. L., Atkinson, R. C., Smith, E. E., Bem, D. J., \& Hoeksema, S. N. (1999). Psikolojiye giriş [Hilgard's Introduction to Psychology]. (Y. Aloğan, Trans.) Ankara: Arkadaş Yayınevi.

Ayık, A., \& Ataş, Ö. (2014). The relationship between pre-service teachers' attitudes towards the teaching profession and their motivation to teach. Journal of Educational Research, 4(1), 25-43. https://doi.org/10.12973/jesr.2014.41.2

Azar, A. (2010). In-service and pre-service secondary science teachers' self-efficacy beliefs about science teaching. Zonguldak Karaelmas University Journal of Social Sciences, 6(12), 235-252.

Bandura, A. (1989). Human agency in social cognitive theory. American Psychologist, 44, $1175-1184$. https://doi.org/10.1037/0003-066X.44.9.1175

Basım, H. N., Çetin, F., \& Tabak, A. (2009). The relationship between big five personality characteristics and conflict resolution approaches. Turkish Journal of Psychology, 24(63), 20-37.

Berry, C. M., Li, N., \& Gardner, R. G. (2011). The five-factor model of personality traits and organizational citizenship behaviours: A meta-analysis. Journal of Applied Psychology, 96(6), 1140-1166. https://doi.org/10.1037/a0024004

Brown, D. (2003). Career information, career counseling and career development. USA: Pearson Education. 
Burger, J. M. (2006). Kişilik: Psikoloji biliminin insan doğasına dair söyledikleri. [Personality], (İ. D. E. Sarıŏlu, Trans.), İstanbul: Kaknüs Yayınevi. (Orginal work published 2004).

Çapa, Y., Çakıroğlu, J., \& Sarıkaya, H. (2005). The development and validation of aTurkish version of the teachers' sense of efficacy scale. Education and Science, 30(137), 74-81.

Ciccarelli, S. K., \& White, J. N. (2016). Psikoloji: Bir keşif gezintisi. [Psychology: An exploration], (D. N. Şahin, Trans. Ed.) Ankara: Nobel.

Cohen, L., Manion, L., \& Morrison, K. (2007). Research methods in education. 6th ed. Taylor \& Francis e-Library.

Costa, P. T., \& McCrae, R. R. (1995). Domains and facets: Hiyerarchical personality assessment using the revised neo personality inventory. Journal of Personality Assessment, 64(1), 21-50. https://doi.org/10.1207/s15327752jpa6401_2

Crant, J. M. (2006). Personality and Careers. In Encyclopedia of career development, edited by J. Greenhaus and G.Callanan, 627-634. CA: SAGE. https://doi.org/10.4135/9781412952675.n220

Demirtaş, H., Cömert, M., \& Özer, N. (2011). Pre-service teachers' self-efficacy beliefs and attitudes towards profession. Education and Science, 36(159), 96-111.

Demirtaş, Z., \& Aksoy, G. P. (2016). Investigation of pedagogical formation certification program students' attitudes towards teaching profession in terms of some variables. International Journal of Educational Research Review, 2458, 21.

Djigic, G., Stojiljkovic, S., \& Doskovic, M. (2013). Basic personality dimensions and teachers' self-efficacy. Procedia-Social and Behavioral Sciences, 112(2014), 593-602.

Ebstrup, J. F., Eplov, L. F., Pisinger, C., \& Jorgensen, T. (2011). Association between the five-factor personality traits and perceived stress: Is the effect mediated by general self-efficacy? Anxiety, Stress and Coping, 24(4), 407-419. https://doi.org/10.1080/10615806.2010.540012

Ekici, G., Çıbık, A. S., \& Fettahlığlu, P. (2014). The predictive power of biology self-efficacy belief and teaching profession self-efficacy belief on the attitude towards teaching profession. Gazi University, Journal of Gazi Educational Faculty, 34(1), 23-41.

Erdheim, J., Wang, M., \& Zickar, M. J. (2006). Linking the big five personality constructs to organizational commitment. Personality and Individual Differences, 41, 959-970. https://doi.org/10.1016/j.paid.2006.04.005

Fadlelmula, F. K. (2013). Attitudes of pre-service teachers towards teaching profession. Turkish Journal of Education, 2(4), 55-63.

Fraenkel, J. R., \& Wallen, N. E. (2003). How to design and evaluate research in education. 5th Ed. New York: McGraw-Hill.

Gerrig, R. J., \& Zimbardo, P. G. (2014). Psikoloji ve Yaşam [Psychology and Life], (G. Sart, Trans.), Ankara: Nobel.

Goddard, R. D., Hoy, W. K., \& Woolfolk-Hoy, A. W. (2004). Collective efficacy beliefs: Theoretical developments, empirical evidence, and future directions. Educational Researcher, 33(3), 3-13. https://doi.org/10.3102/0013189X033003003

Goldberg, L. R. (1981). Language and individual differences: The search for universals in personality lexicons. In Review of Personality and Social Psychology, edited by L. Wheeler, 141-165. CA: Sage.

Goldberg, L. R. (1990). An alternative description of personality: The big-five factor structure. Journal of Personality and Social Psychology, 59, 1216-1229. https://doi.org/10.1037/0022-3514.59.6.1216

Hartman, R. O., \& Betz, N. E. (2007). The five -factor model and career self-efficacy: General and domain specific relationships. Journal of Career Assessment, 15(2), 145-161. https://doi.org/10.1177/1069072706298011

Hockenbury, D. H., \& Hockenbury, S. E. (2010). Psychology. New York: Worth.

Hogg, M. A., \& Vaughan, G. M. (2007). Sosyal Psikoloji. [Social Psychology], (İ. Yıldız \& A. Gelmez, Trans), Ankara: Ütopya. (Original work published 2005).

Jamil, F. M., Downer, J. T., \& Pianta, R. C. (2012). Association of pre-service teachers' performance, personality, and beliefs with teacher self-efficacy at program completion. Teacher Education Quarterly, Fall, 119-138.

Jogovic, I., Marusic, I., Ivanec, T. P., \& Vidovic, V. V. (2012). Motivation and personality of pre-service teachers in Croatia. Asia-Pacific Journal of Teacher Education, 40(3), 271-287.

https://doi.org/10.1080/1359866X.2012.700044 
Kadı, A., Beytekin, O. F., \& Arslan, H. (2015). A research on the burnout and the teaching profession attitudes of teacher candidates. Journal of Education and Training Studies, 3(2), 107-113. https://doi.org/10.11114/jets.v3i2.677

Kağıtçıbaşı, Ç. (2010). Günümüzde İnsan ve İnsanlar: Sosyal Psikolojiye Giriş. İstanbul:Evrim Yayınevi.

Klassen, R. M., \& Tze, V. M. C. (2014). Teachers' self-efficacy, personality, and teaching effectiveness: A meta-analysis. Educational Research Review, 12, 59-76. https://doi.org/10.1016/j.edurev.2014.06.001

Kutlu, N., Gökdere, M., \& Çakır, R. (2015). The relationship between prospective teachers' academic procrastination behavior and their attitude towards teaching as a profession. Kastamonu Educational Journal, 23(3), 1311-1330.

Kutluca, T., \& Ekici, G. (2010). Examining teacher candidates' attitudes and self-efficacy perceptions towards the computer assisted education. Hacettepe University Journal of Education, 38, 177-188.

Oğuz, E., \& Kalkan, M. (2011). Examining teacher candidates' attitudes towards teaching profession and pupil control ideology. International Online Journal of Educational Sciences, 3(3), 903-917.

Ömür, Y. E., \& Nartgün, Ş. S. (2013). Relationship between prospective teachers' attitudes towards teaching profession and their motivation levels. Journal of Educational Policy Analysis, 2(2), 41-55.

Özdemir, S. M. (2008). An investigation of prospective primary teachers' self-efficacy beliefs regarding teaching process in terms of certain variables. Educational Administration: Theory and Practice, 54, 277-306.

Panaccio, A., \& Vandenberghe, C. (2012). Five-factor model of personality and organizational commitment: The mediating role of positive and negative affective states. Journal of Vocational Behaviour, 80, 647-658. https://doi.org/10.1016/j.jvb.2012.03.002

Pandey, N. S., \& Kavitha, M. (2015). Relationship between big five personality and job satisfaction of private high school teachers, in Puducherry region: An Empirical analysis. International Journal of Research in Economics and Social Sciences, 5(8), 245-253.

Pehlivan, K. B. (2010). A study on prospective teachers' learning styles and their attitudes toward teaching profession. Elementary Education Online, 9(2), 749-763.

Plotnik, R. (2009). Psikolojiye giriş. [Introduction to Psychology], (T. Geniş, Trans.), İstanbul: Kaknüs Yayınevi. (Orginal work published in 2007).

Robbins, S. P., \& Judge, T. A. (2012). Örgütsel Davranış (Organizational Behavior). (İ. Erdem, Trans.), Ankara: Nobel Yayınevi. (Orginal work published in 2011).

Salgado, J. F., Viswesvaran, C., \& Ones, D. S. (2001). Predictors used for personnel selection: An overwiev of constructs, methods and techniques. In Handbook of Industrial Work and Organziational Psychology, edited by N. Anderson, D.S. Ones, H.K. Sinangil and C. Viswesvaran, 165-199. London: SAGE. https://doi.org/10.4135/9781848608320.n10

Saracaloğlu, A. S., \& Yenice, N. (2009). Investigating the self-efficacy beliefs of science and elementary teachers with respect to some variables. Journal of Theory and Practice in Education, 5(2), 244-260.

Schmitt, D. P., Allik, J., McCrae, R. R., \& Martinez, V. B. (2007). The geographic distribution of big five personality traits: Patterns and profiles of human self-description across 56 nations. Journal of Cross-Cultural Psychology, 38, 173-212. https://doi.org/10.1177/0022022106297299

Shaw, M. E. (1981). Group Dynamics: The psychology of small group behavior. NY: McGraw Hill.

Shrout, P. E., \& Bolger, N. (2002). Mediation in experimental and nonexperimental studies: new procedures and recommendations. Psychological Methods, 7(4), 422. https://doi.org/10.1037/1082-989X.7.4.422

Sümer, N., Lajunen, T., \& Özkan, T. (2005). Big five personality traits as the distal predictors of road accident involvement. Paper presented at the $3^{\text {rd }}$ international conference on traffic and transport psychology, Nottingham, UK, September 5-9. https://doi.org/10.1016/B978-008044379-9/50173-4

Tarkın, A., \& Uzuntiryaki, E. (2012). Investigation of pre-service teachers' self-efficacy beliefs and attitudes toward teaching profession through cononical analysis. Elementary Education Online, 11(2), 332-341.

Terzi, A. R., \& Tezci, E. (2007). The attitudes of the students towards teaching profession at Necatibey education faculty. Educational Administration: Theory and Practice, 52(52), 593-614.

Tschannen-Moran, M., \& Woolfolk-Hoy, A. (2001). Teacher efficacy: Capturing an elusive construct. Teaching and Teacher Education, 17, 783-805. https://doi.org/10.1016/S0742-051X(01)00036-1 
Üstüner, M. (2006). Reliability and validity study of an attitude scale of teaching profession. Educational Administration: Theory and Practice, 12(45), 109-127.

Üstüner, M., Demirtaş, H., \& Cömert, M. (2009). The attitudes of prospective teachers towards the profession of teaching: The case of İnönü University, Faculty of Education. Education and Science, 34(151), 140-155.

Yenice, N. (2012). Investigation the self-efficacy and problem solving skills of pre-service teachers. Electronic Journal of Social Sciences, 11(39), 36-58.

\section{Copyrights}

Copyright for this article is retained by the author(s), with first publication rights granted to the journal.

This is an open-access article distributed under the terms and conditions of the Creative Commons Attribution license which permits unrestricted use, distribution, and reproduction in any medium, provided the original work is properly cited. 